\title{
FLOWER STUDIES DO NOT SUPPORT SUBSPECIES WITHIN PINGUICULA MACROCERAS
}

\author{
BARRY RICE $\bullet$ Center for Plant Diversity • U niversity of California $•$ Davis, California $95616 \cdot$ USA \\ -barry@sarracenia.com
}

Keywords: Field studies: Pinguicula macroceras, California.

\begin{abstract}
A bstract
How much do the flowers of Pinguicula vary in size from site to site? To explore this and related questions, flowers of Pinguicula macroceras from different Californian colonies were studied. It was found that different colonies, even if separated by only small distances, can have significantly different typical flower sizes. These differences are even greater than the differences that were used to define subspecies within Pinguicula macroceras. A s such, there is inadequate evidence to support subspecific divisions within P. macroceras.
\end{abstract}

\section{Introduction}

As shown in Figure 1, Pinguicula macroceras Link ranges from the western USA, north to Canada, and west to Russia and Japan (Casper 1966; Schlauer 2002; Schnell 2002). The range is highly uncertain as can be seen by comparing the maps in Casper (1966) and Schnell (2002), and is a topic worthy of further study. The species is often divided into two subspecies: Pinguicula macroceras Link subsp. macroceras and Pinguicula macroceras subsp. nortensis J. Steiger \& J.H. Rondeau (Rondeau \& Steiger 1997). The details of the differences between the two subspecies are noted in the discussion, but briefly they are (1) the spur and corolla length, (2) the shape and degree of overlap in the lower corolla lobes, and (3) the shape of the tips of the calyx lobes.

Recently, a population of Pinguicula in the Castle $\mathrm{C}$ rags district of north-central California was investigated for the first time (Rice et al. 2008; hereafter RY M 2008). This location represented a range extension for P inguicula macroceras, and it was not clear whether the plants should be classified as P inguicula macroceras subsp. nortensis or Pinguicula macroceras subsp. macroceras. While the $\mathrm{C}$ astle $\mathrm{Crags}$ plants were geographically closest to the range of Pinguicula macroceras subsp. nortensis, the flowers were larger $(24-38 \mathrm{~mm})$ than the size described for Pinguicula macroceras subsp. nortensis (13-21 mm). This discovery encouraged further study, especially of the variability of flower sizes within the species.

Within its range, Pinguicula macroceras subsp. nortensis occurs in pocket populations that are separated by distances both large and small. The overall character of the plants (for example, flower sizes) may be different from site to site. However, taken as a whole, the variation of the plants still falls within the definition of the species, P inguicula macroceras. M eanwhile, how important are the floral differences that are used to distinguish the two subspecies of Pinguicula macroceras? While the variation in site-to-site flower sizes may be due to both environmental and genetic differences, if the site-to-site differences in Pinguicula macroceras subsp. nortensis plants is greater than the differences used to define the two subspecies, then the subspecies separation is not merited. The current study, therefore, explores this variation within Pinguicula macroceras in California. 


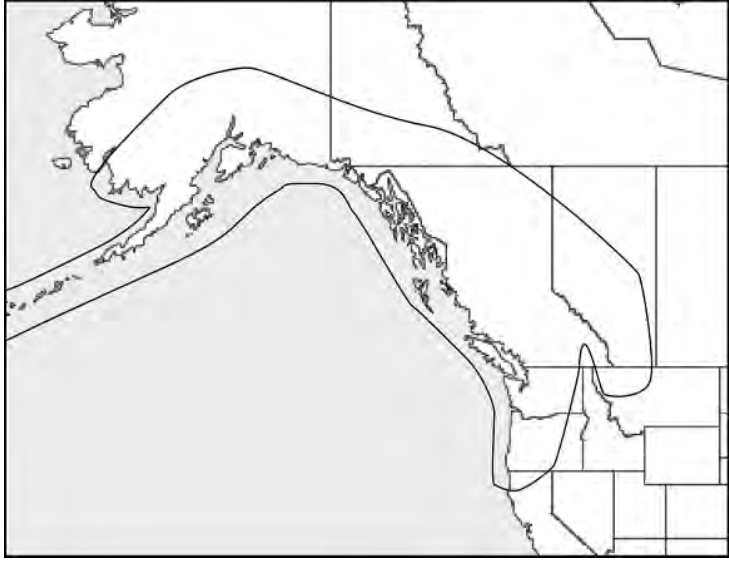

Figure 1: The range of Pinguicula macroceras in North America. The boundaries of the range are uncertain, especially along the western coast of Alaska. Within the range indicated, sites are often separated by great distances.

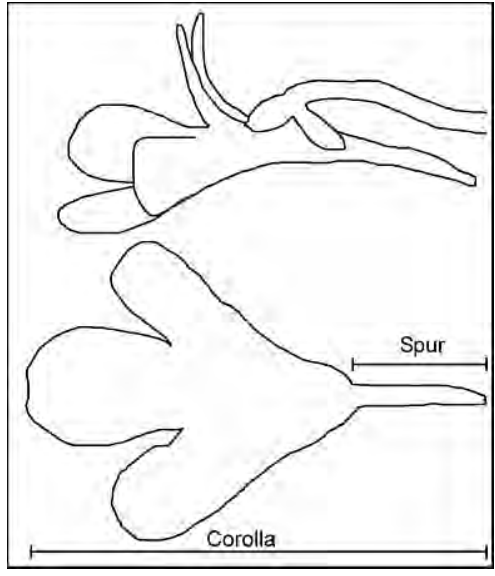

Figure 2: Outlines of typical flowers; the top outline is viewed from the side, the bottom is viewed from below. The bottom view is labeled to indicate the distances measured for the corolla length and spur length.

M ethod

The region around Gasquet, Del Norte County (California, USA) is arguably the population center for Pinguicula macroceras subsp. nortensis. Five sites in the area were studied during 3-4 $M$ ay 2008. These sites are within $15 \mathrm{~km}$ of each other, but span a range of microclimatic conditions and soil characteristics.

Site 1: A gentle south-facing slope seepage in a sparse conifer woodland with loamy soil; 150 $m$ a.s.l. Forty flowers sampled.

Site 2: A north-facing population of plants on the steep rocky banks of a small creek, soil occurs in small patches but reasonably well developed; $120 \mathrm{~m}$ a.s.l. Thirty flowers sampled.

Site3: A n east-facing roadside population of plants on a scree slope, the soil consists entirely of serpentinic chips; $145 \mathrm{~m}$ a.s.l. Thirty flowers sampled.

Site4: A north-facing roadside population of plants growing on a sheer serpentine cliff; 135 m a.s.l. Two sub-populations were sampled at this location. The first sub-population ("4a") consisted of plants adhering directly to the barren cliff wall. The second sub-population (" $4 b$ ") consisted of plants that grew on the pure serpentinic gravel at the cliff base. The second sub-population was clearly derived from individuals from the first sub-population, which had detached from the cliff wall and had become established on the scree at the cliff base. Thirty flowers were sampled from each sub-population.

Site5: A north-facing population on a steep slope, the soil was pure serpentinic gravel; $45 \mathrm{~m}$ a.s.l. Two intermingling sub-populations were sampled. The first sub-population ("5a") consisted of normally pigmented plants. The second sub-population (" $5 \mathrm{~b}$ ") consisted of plants with foliage that was suffused with brown pigmentation (i.e., "chocolate plants."). Thirty flowers were sampled from each sub-population.

Castle Crags district: This north-facing population, investigated in RY M 2008, occurs on wet serpentinic rock and scree with moderately well developed soil; $1840 \mathrm{~m}$ a.s.l. Thirty-four flowers were sampled by RY M 2008. 


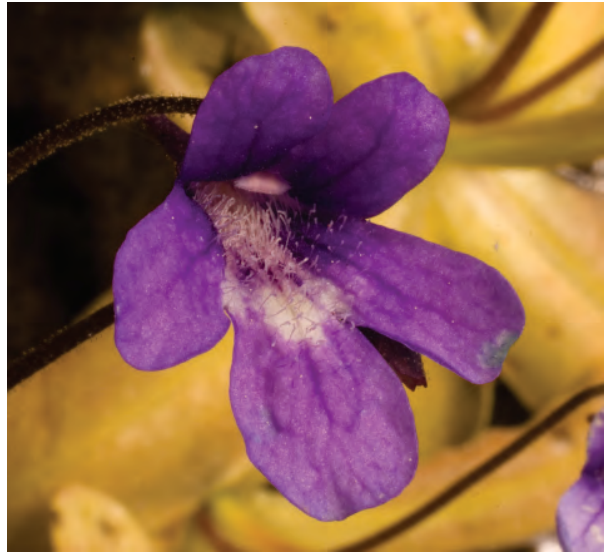

Figure 3: Pinguicula macroceras flower from Site $5 b$.

At each site, thirty or more flowers were selected (no more than one flower per plant). M easurements were taken of the length of their spurs (from tip to the point where the corolla tube flared; see Figures 2 and 3 ) and the entire length of the flowers (from spur tip, to distal margin of lower corolla lobe). Flowers were measured by gently lowering them onto the surface of a ruler, until the bottom of the flower was flat against the ruler; care was taken to avoid stretching the flower tissue. All measurements were made without damaging the plants or flowers.

\section{Results}

The averages and standard deviations for the spur and corolla lengths are given in Table 1. In his important paper on Pinguicula macroceras, Casper (1962) created histograms of his flower measurements (i.e., numbers of flowers plotted as a function of corolla or spur length). In order to compare my data to his, histograms were created following his method. Specifically, Casper normalized each histogram so its peak reached a y-value of 1.0. He noted the $x$-points where the $y$-value of the histogram was equal to $1 / 2$, and used these $x$-points to define the range of corolla lengths. Rondeau \& Steiger (1997) do not explain how they devel oped their ranges in corolla or spur lengths; presumably they used the same method.

In RY M 2008, character ellipses were used to study flower morphology. This method of presenting data, while novel and unconventional, neatly illustrates the two-dimensional data set (corolla lengths and spur lengths) for different sites simultaneously. To understand character ellipses, consider the data

\begin{tabular}{|c|c|c|c|c|}
\hline \multirow[b]{2}{*}{ Site/population } & \multicolumn{2}{|c|}{ Spur length (mm) } & \multicolumn{2}{|c|}{ Corolla size $(\mathrm{mm})$} \\
\hline & Ave $\pm 1 \sigma$ & From histograms & Ave $\pm 1 \sigma$ & From histograms \\
\hline Site 1 & $8.1 \pm 1.0$ & (6)6.5-9.5(10) & $26 \pm 2.7$ & $(21) 22.5-30(32)$ \\
\hline Site 2 & $9.2 \pm 1.1$ & $(7) 8-10.5(11)$ & $32 \pm 2.5$ & (27)29-35.5(38) \\
\hline Site 3 & $5.7 \pm 0.8$ & (4)4.5-7 & $21 \pm 2.5$ & (15)19.5-24.5(26) \\
\hline Site 4a (cliff wall) & $7.0 \pm 0.9$ & $6-9(9)$ & $24 \pm 2.0$ & $(22) 22.5-25.5(30)$ \\
\hline Site 4b (cliff base) & $6.6 \pm 0.8$ & (5) $5.5-8$ & $27 \pm 2.6$ & $22-31$ \\
\hline Site 5a (typical plants) & $6.8 \pm 0.9$ & (5) $5.5-8(9)$ & $26 \pm 2.4$ & (22) $23-28.5(31)$ \\
\hline Site 5b (brown plants) & $6.3 \pm 1.0$ & $5-7.5(9)$ & $23 \pm 2.3$ & (18)21.5-24.5(28) \\
\hline All plants (Sites 1-5b) & $7.1 \pm 1.4$ & $(4) 5.5-8.5(11)$ & $26 \pm 3.9$ & (15)22.5-28(38) \\
\hline Castle Crags & $6.6 \pm 0.7^{1}$ & $(1.5) 6-8(9)^{1}$ & $25 \pm 1.4^{1}$ & (17) $24-28 \mathrm{~mm}^{1}$ \\
\hline Pinguicula macroceras & --- & $(1) 6-9(11)^{2}$ & --- & $(12) 18-27(30)^{2}$ \\
\hline
\end{tabular}




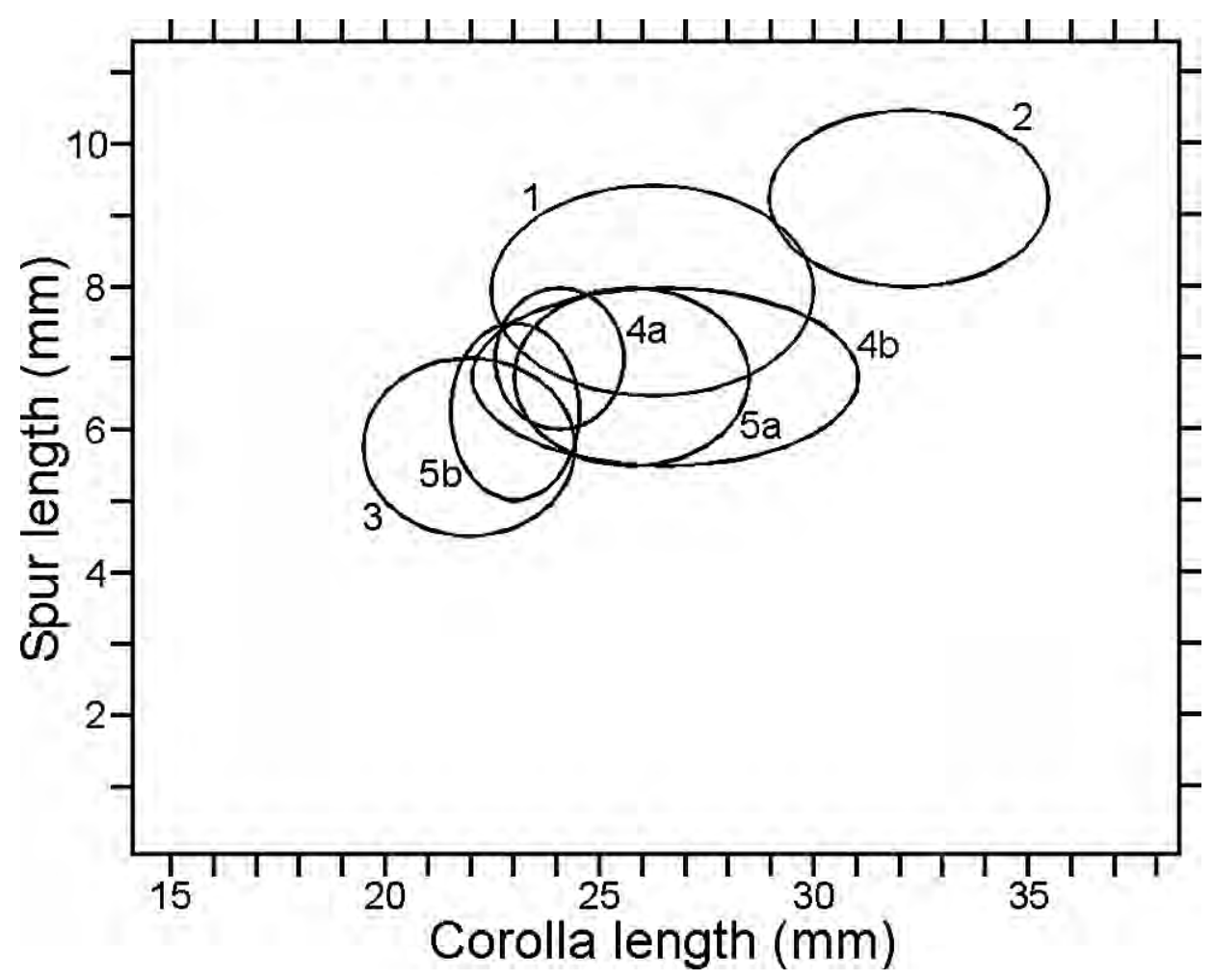

Figure 4: Inner range character ellipses for the seven populations of Pinguicula macroceras studied in Del Norte County. The different populations appear to exhibit distinct size ranges. In creating this figure, the vertical and horizontal major axes of each ellipse are set by the spur length range, and corolla length range, respectively. The values used are those for the inner ranges given for each character in Table 1 (i.e., 6.5-9.5 $\mathrm{mm}$ for the spur length for the plants from Site 1). Each ellipse is labeled with population number, where each label is placed just outside its corresponding ellipse.

for Site 1 in Table 1. The histogram spur lengths and corolla sizes for Site 1 were 6.5-9.5 mm and 22.5-30 mm respectively. The character ellipse for this would be drawn so that the ellipse's vertical axis ranges from 6.5 to $9.5 \mathrm{~mm}$, and the horizontal axis ranges from 22.5 to $30 \mathrm{~mm}$ (see Figure 4).

\section{Discussion}

The first question to be addressed is whether or not there are significant differences among the seven populations sampled in Del N orte County. Figure 4 shows the character ellipses for the spurs and corollas. Clearly, the spur and corolla lengths for each population fall in different places on this diagram. If these data were interpreted with an eye for detecting small differences, the populations might appear significantly different. It might even be argued they should be recognized as separate taxa. For example, without the data from Sites 1, 4, and 5 included, the plants from Site 2 and Site 3 look like two different taxa on this diagram, but they are not. The lesson here is that an inadequate sample of a population can result in the illusion that separate taxa exist, only because the intermediate plants had been overlooked. 


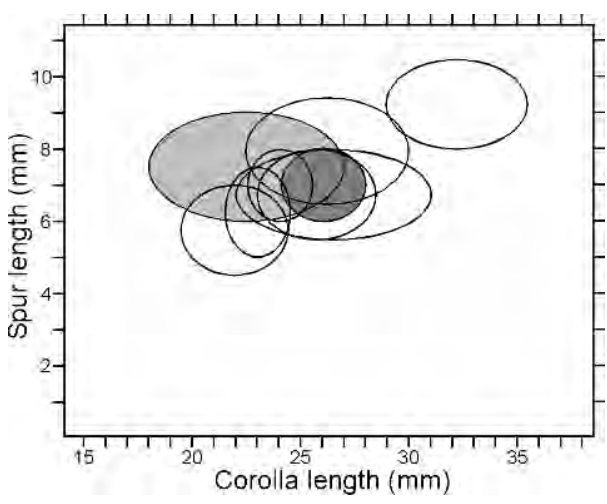

Figure 5: Data from Figure 4 repeated. Also shown are the inner character ellipses for the Castle Crags data (dark grey) and Casper's values for Pinguicula macroceras s. lat. (light grey). Notice that both are reasonably coincident with the range of Pinguicula macroceras in Del Norte County.
The second question asks are the site-tosite differences in flower characteristics purely genetic? The data suggest that differences are at least partly environmental- the populations with the largest flowers (i.e., at Sites 1 and 2) occurred on well developed soils (i.e., loam soils with large fraction of organic material), while the soils at the Sites 3,4 , and 5 consisted of pure, serpentinic gravel chips. The two sub-populations at Site 4 grew in different exposures (i.e., on a cliff wall vs. on the flats at the base of the cliff), but the substrate for both sub-populations was the same pure serpentinic gravel chips; as such, there were no significant differences between their flower characteristics. This suggests that soil type may be more important than soil slope or wind exposure.

In order to look for genetic influences, reciprocal transplants or common greenhouse studies would be necessary, but that was beyond the scope of this study. Interestingly, while the two subpopulations at Site 5 were separated on the basis of leaf coloration (normal green leaves vs. brown leaves), there were no significant differences between their floral characteristics. However, there is a slight difference (the chocolate-colored plants tended to have slightly smaller flowers), and this could be an avenue of further study.

The third question asks how do the plants from the Castle Crags district fit into this analysis? Figure 5 repeats the data shown in Figure 4, but also includes character ellipses for the population from Castle Crags district (shaded dark grey; from RY M 2008), and Pinguicula macroceras s. lat. (shaded light grey; from Casper 1962). It is clear that the Castle Crags plants fall well within the range of variability for plants in California. The flowers are not morphologically different from other $\mathrm{C}$ al ifornian plants.

The fourth question asks if the data support the separation of Pinguicula macroceras s. lat. into two subspecies. The strongly overlapping character ellipses in Figure 5 clearly illustrate that there is no floral evidence to separate the recognition of the taxon Pinguicula macroceras subsp. nortensis.

W hile flower size was an important characteristic used in the original description of Pinguicula macroceras subsp. nortensis, it was not the only one. A nother character was the shape and degree of overlap of the lower corolla lobes- large in P. macroceras subsp. macroceras, small in P. macroceras subsp. nortensis (Rondeau \& Steiger 1997; Steiger 1975). In practice, the supposed degree of petal overlap is not readily visible (see discussion in RY M 2008). Further, photographs of P. macroceras subsp. macroceras from J apan, both in the wild and in cultivation, clearly illustrate the lack of corolla overlap (Partrat 2005; Takai 1995).

Since floral size and corolla overlapping do not appear to be significant characteristics, the only remaining difference between the two subspecies is the nature of the tips of the calyx lobes. This attribute was addressed in neither the current study nor in RY M 2008. However, such a minor detail surely does not merit subspecific designation. Therefore, I conclude that Pinguicula macroceras subsp. nortensis should no longer be recognized as a significant entity, and should be reduced to synonymy of Pinguicula macroceras.

The general philosophy of this discussion can be extended to other butterwort species of Europe and M exico, which are sometimes the subject of contentious disagreement between lumping and 
splitting botanists. The inherent variability of Pinguicula in Del Norte County is a reminder to proceed cautiously.

Acknowledgements: I wish to thank Elizabeth Salvia and B ob Ziemer for help in the field, Harry Tryon for guidance to sites I was unfamiliar with, and J im M iller for his companionship in the field. I also thank Fernando Rivadavia for many useful suggestions that improved drafts of this paper. No permits were required to visit the public and unposted private locations described in this paper. No specimens were collected during the course of study.

\section{References}

Casper, S.J. 1962. On P inguicula macroceras Link in North A merica. R hodora 64: 212-221.

Casper, S.J. 1966. M onographie der Gattung Pinguicula L. Stuttgart: Bibliotheca Botanica Heft 127/128: p171-179, Figure 45.

Partrat, E. 2005. Pinguicula macroceras, http://www.pinguicula.org/pages/plantes/pinguicula_ macroceras.htm, accessed J une 2010.

Rice, B., Y in, A ., and M orimoto, G.E. 2008. Observations of isolated Pinguicula populations in the western USA . Carniv. PI. N ewslett. 37: 100-109.

Rondeau, J.H., and Steiger, J.F. 1997. Pinguicula macroceras subsp. nortensis, a new subspecies of Pinguicula (Lentibulariaceae) from the California-Oregon border. International Pinguicula Study Group N ewsletter 8: 3-8.

Schlauer, J. 2002. World Carnivorous Plant List--Nomenclatural Synopsis of Carnivorous Phanerogamous Plants, http://www.omnisterra.com/bot/cp_home.cgi, accessed J une 2010.

Schnell, D.E. 2002. Carnivorous plants of the U nited States and Canada. (2nd Edition) Timber Press, Portland, 468p, p296-308.

Steiger, J.F. 1975. The P inguicula species of the temperate growth type and their cultivation. Carniv. PI. Newslett. 4: 8-18.

Takai, I. 1995. Pinguicula macroceras, photographs, http://www.omnisterra.com/botany/cp/ pictures/pinguicu/0050.htm, accessed J une 2010.

\section{THE \\ ICPS SEED BANK

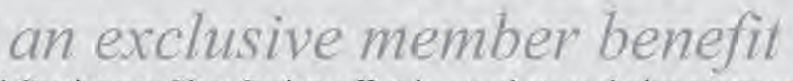

The International Carnivorous Plant Society offers its members exclusive access to a variety of carnivorous plant seeds. Seeds are ordered online at the ICPS Store:

\section{http://icps.clubexpress.com/}

The Seed Bank cannot exist without seed donations. Information about growing carnivorous plants from seed and donating seeds to the Seed Bank are at the ICPS public web site:

\section{http://www.carnivorousplants.org/seedbank}

If you do not have access to the Internet, please send seed order form requests to:

International Carnivorous Plant Society

1564-A Fitzgerald Drive, PMB 322

Pinole, CA 94564-2229

JOHN BRITTNACHER, Seed Bank Manager, john@carnivorousplants.org 


\section{CARNIVOROUS PLANT \\ NEWSLETTER}

Journal of the International Carnivorous Plant Society

Volume 40, No. 2

J une 2011

WWI

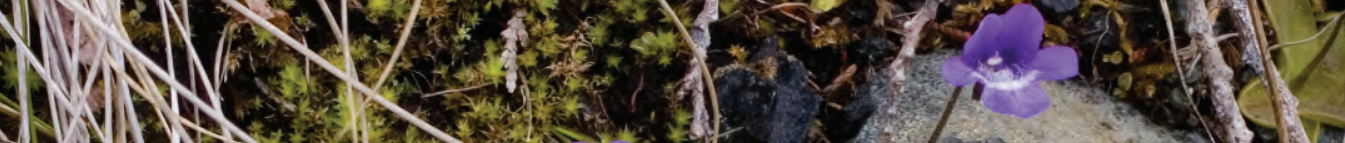

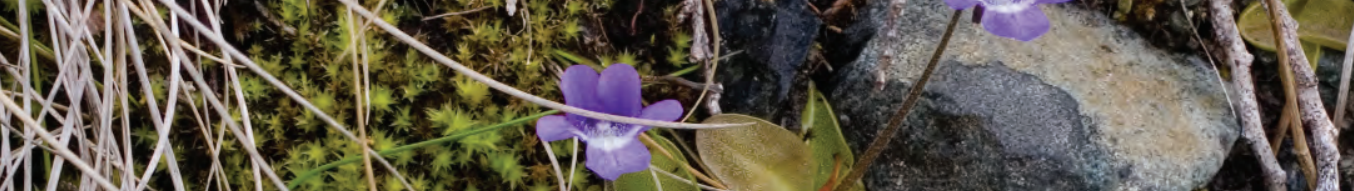

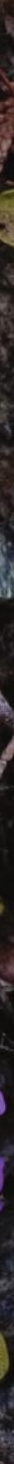




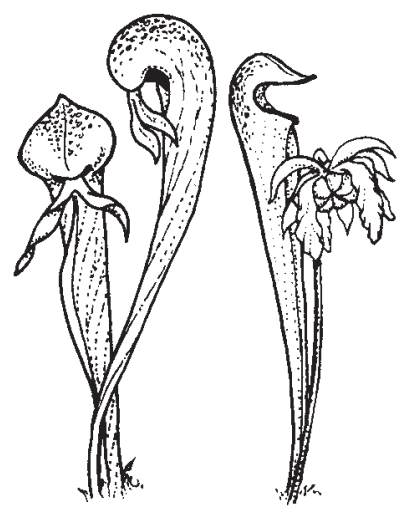

\section{CARNIVOROUS \\ PLANT \\ NEWSLETTER}

Journal of the International

Carnivorous Plant Society

www.carnivorousplants.org

Volume 40, Number 2 June 2011

Front Cover: Pinguicula macroceras at Site 5, in California. Photo by Barry Rice. Article on page 44.

\section{Back Cover: Barry Rice wrassling with Utricularia foliosa in western Florida. Photo by Elizabeth Salvia.}

Carnivorous Plant Newsletter is dedicated to spreading knowledge and news related to carnivorous plants. Reader contributions are essential for this mission to be successful. Do not hesitate to contact the editors with information about your plants, conservation projects, field trips, or noteworthy events. A dvertisers should contact the editors. Views expressed in this publication are those of the authors, not the editorial staff.

All correspondence regarding dues, address changes and missing issues should be sent to the Membership Coordinator at the ICPS. D o not send such correspondence to the editors. Checks for subscriptions should be made to the ICPS in US funds. Dues for 2011 are \$35 for the first year of membership; renewals are $\$ 30$ per year.

ICPS, Inc.
PM B 322
1564-A Fitzgerald D rive
Pinole, CA 94564-2229, USA
icps@ carnivorousplants.org

President Michael Baldwin, michael@ carnivorousplants.org

Vice President M M Marcel van den Broek, marcel@ carnivorousplants.org

Secretary Cindy Slezak, cindy@carnivorousplants.org

Treasurer

Richard M yers, richard@ carnivorousplants.org

B oard M ember Bob Ziemer, bob@carnivorousplants.org

B oard M ember Jan Schlauer, jan@ carnivorousplants.org

B oard M ember B B Bian Barnes, Conservation Director, brian@ carnivorousplants.org

Seed B ank M anager J ohn B rittnacher, john@ carnivorousplants.org (see seed bank ad in this issue)

Editors:

M anaging Editor Bob Ziemer, bob@carnivorousplants.org

Science Editor Jan Schlauer, jan@ carnivorousplants.org

Science Editor Fernando Rivadavia, fernando@ carnivorousplants.org

Editor

Barry Rice, barry@ carnivorousplants.org

Date of effective publication of the M arch 2011 issue of Carnivorous Plant N ewsletter: 1 M arch 2011.

The ICPS is the International Cultivar Registration A uthority (ICRA) for the names of cultivated carnivorous plants according to the International Code of Nomenclature for Cultivated Plants. Send relevant correspondence to the ICPS, Inc.

Carnivorous Plant Newsletter is published quarterly in M arch, June, September, and December by the ICPS, Inc. Periodicals postage pending at Richmond, $\mathrm{CA}$ and additional mailing offices. Postmaster: Send address changes to ICPS, Inc., PM B 322, 1564-A Fitzgerald Drive, Pinole, CA 94564-2229, USA. Printed by A llen Press, Inc., 810 E. 10 th Street, L awrence, K S 66044. Logo and masthead art: Paul M ilauskas.

(c) 2011 Carnivorous Plant N ewsletter. All rights reserved. ISSN \#0190-9215 